\title{
SZEMLE
}

\section{TÖRÉKENY HATÁROK: Ahol a POLITIKa ÉS A TUDOMÁNY ÖSSZEÉR}

\author{
ALEXANDROV ANNA \\ ELTE Eötvös Loránd Tudományegyetem, Pszichológiai Doktori Iskola
}

Anna Borgos, Ferenc Erős \& Júlia Gyimesi (eds): Psychology and Politics: Intersections of Science and Ideology in the History of Psy-sciences. Budapest, New York, Central European University Press, vii + 372 p. ISBN: 9789633863121

Ha valamit politikai hatások érnek, az vajon megszünik tudományosnak lenni? Kézenfekvőnek tünik, hogy azt válaszoljuk: igen. Igen, a tudomány értéksemleges, és ha a politika megkisérli átitatni, az szakmaiatlan és nemkivánatos. A helyzet azonban közel sem ennyire egyszerü. A (tágan értelmezett) politika - ideértve például az intézményi politikát és a tudományos szereplők személyes hatókörét, az ideológiát és meggyőződést, vagy akár olyan politikai körülményeket, mint a háború vagy egy tekintélyelvű rendszer - a kezdetektől fogva része volt annak a talajnak, amelyből a tudomány, ezen belül pedig a "pszichotudományok” kinőttek. A Borgos Anna, Erős Ferenc és Gyimesi Júlia által szerkesztett Psychology and Politics tanulmányai is emellett érvelnek; rámutatnak, hogy a "politikai” és a „tudományos" nem különálló szférák, sosem voltak azok, és nem is lehetnek. De ha nem várhatunk politikamentességet a pszichotudományoktól, akkor mit várhatunk? A kötet tanulmányai különféle, általában történeti példákon keresztül mutatnak rá arra a folyamatra, ahogyan a diszciplináris határok, a „tudományos” és „nem tudományos” kategóriái formálódnak - mindmáig.

Azt, hogy miként olvastam ezt a könyvet, meghatározta, hogy pszichológus vagyok. A kötet azonban nemcsak pszichológusoknak lehet izgalmas, hanem másoknak is; elsősorban persze azoknak, akik kapcsolódnak a kötet által körbeírt pszichotudományok valamelyik ágához. Ezeket a területeket egyrészt a modern szubjektum meghatározásában és létrehozásában betöltött szerepük tartja össze, másrészt a segítő munka gyakorlata, ideálja - és ez a két tényező szorosan összekapcsolódik.

A történeti szemlélet nem pusztán kutatási módszer a kötetben, hanem fontos eszköze a tudományos univerzalitás és objektivitás kritikájának, amely a kötet egyik fó tárgya. Ha egy tudományos elképzelést elhelyezünk egy adott történelmi kontextusban, és megmutatjuk, miként alakította az a kontextus, akkor egyúttal kritika alá vonjuk az elképzelés „mindentől függet- 
len" örökkévalóságát, változatlanságát is, akárcsak a politikamentességét. Hozzá kell tenni, hogy a „politika” fogalma a kötetben tágabb értelemben jelenik meg, mint ahogy a hétköznapi életben használjuk. Nem pártpolitikát jelent, nem is mindig hagyományos értelemben vett világpolitikai eseményeket (bár a kötet egy-egy tanulmánya ezekről is szót ejt - például háborúkkal, diktatúrákkal hoz összefüggésbe pszichotudományos fejleményeket), hanem idetartozik a társadalmi berendezkedés egésze, annak minden feszültségével és egyenlőtlenségével. A kötet egyik fó állítása, hogy a tudománypolitika és az egyéb („külső”) politikák nem függetlenek egymástól.

A kötet szerzői - azzal összhangban, hogy a tudományos eredmények tér- és időfüggetlenségét vonják kétségbe - törekszenek konkrét esetek (föleg kelet- és közép-európai témák) feldolgozására. $\mathrm{A} z$ egyik szerző, Ruszlan Mitrofanov az, aki talán a legvilágosabbá teszi a kelet-európai fókusz lényegét: jóllehet a kötet több tanulmánya támaszkodik Michel Foucault munkáira, Mitrofanov a foucault-i pszichiátriaelemzés kritikátlan alkalmazása ellen érvel más (értsd: nem francia) társadalmi kontextusok elemzésekor. Ez egyben azt is jelenti, hogy a kötet a keleteurópai pszichotudományok történetét nem a nyugat-európai történelem „fejletlenebb" másának, esetleg - a Mitrofanov (274. o.) által kritizált szóval élve „különutas” változatának tekinti, hanem saját jogán vizsgálható kontextusnak, amely azonban természetesen összeköttetésben állt, áll más régiókkal.

$\mathrm{A} z$ írások számos témát járnak körbe, és bár egy részük szorosan kapcsolódik egymáshoz (sőt, párbeszédben állnak), néhányuk kissé elkülönül a többitől. A szerkesztői munka - a fejezetek felépítése és a bevezetőben vázolt ív - sokat segít ennek az ellentmondásnak a feloldásában. $\mathrm{Az}$ egyetlen hiányérzetem a kötet befejezésekor abból fakadt, hogy örömmel alkottam volna még átfogóbb képet a pszichotudományok számtalan ágazatáról. Annak a benyomásomnak, hogy a kötet nem teljesen "fedi le" a témáját, részben a vállalkozás léptéke lehet az oka (a pszichotudományok rendkívül tág területet képviselnek), részben pedig az, hogy a kötet egy konferencia ${ }^{1}$ nyomán született.

Terjedelmi okokból nem térhetek ki mind a huszonkét tanulmány összegzésére, így az alábbiakban csak arra teszek kísérletet, hogy vázoljam a kötet felépítését, és néhány példával illusztráljam a központi témákat. Elsősorban arra fogok kitérni, hogy 1) mi mindent ért a kötet „politika” alatt a pszichotudományokkal összefüggésben, illetve 2) milyen kutatási és gyakorlati elveket, irányokat állítanak követendő mintaként az olvasó elé a tanulmányok.

A könyv öt fejezetre oszlik - az ív a pszichoanalízistől a pszichiátrián át a kritikai pszichológiáig nyúlik. Az első fejezet középpontjában a pszichoanalízis áll: annak társadalmi megítélése, de ezzel összefüggésben egyéni életutakban játszott szerepe is. A következő fejezet szintén a pszichoanalízis történetéből villant fel szakaszokat, elsősorban Ferenczi Sándor és Róheim Géza alakjaihoz kötődően. A kötet harmadik fejezete a pszichotudományok diktatúrák idején vállalt szerepével foglalkozik, míg a negyedik a pszichiátria történetét tárgyalja különféle társadalmi kontextusokban. Végül az ötödik fejezet a kritikai pszichológia

\footnotetext{
A konferencia 2015-ben került megrendezésre Budapesten, és a Psycho-Politics: The Cross-Sections of Science and Ideology in the History of Psy-Sciences címet viselte.
} 
fogalma köré csoportosul, ${ }^{2}$ a hagyományos pszichológiai tudástermelés és gyakorlat kritikájával foglalkozik.

A tanulmányok egy része azt vizsgálja, miként dől el különféle történelmi helyzetekben, a tudósok aktív részvételét igénylő folyamatokon keresztül, hogy mi számít tudományosnak. Ezt teszi például a kötet első tanulmánya, amelyben Michael Molnar a londoni Freud Múzeum történetének egy szakaszán keresztül elemzi a tudomány és a müvészet határának problémáját - és azt a „kapuöri” munkát, amelyet a múzeum intézményi politikája végzett ennek a határnak a „tudományos" oldalán. Gyimesi Júlia tanulmánya is a tudományos határkijelölés politikáját tárgyalja: azt a folyamatot, melynek során Sigmund Freud és a pszichoanalízis más alakjai - a pszichoanalízis és a spiritualizmus találkozásaira felelve - meghatározták, meddig terjedhet az általuk művelt tudomány, és hol kezdődik a tudománytalanság (ebben az esetben az okkultizmus).

A tudomány és politika metszetének kapcsolódó aspektusa az intézménypolitika és a benne érvényesülő személyes hatások kérdése. Több tanulmány (például Gyimesi Júliáé vagy Stephen Froshé) érinti Freud vezetői szerepét és döntéseit a pszichoanalitikus mozgalomban, míg Aleksandar Dimitrijević a fragmentált jelenkori pszichoanalitikus mozgalom egyesítésének szükségességéről és lehetőségeiről ír. Hasonló témát dolgoz fel a tanulmányoknak az a csoportja, amely azzal foglalkozik, hogyan fordult egy-egy pszichotudomány érdeklődése adott történeti kontextusokban adott irányokba. Kovai Melinda az 1945 és 1970 közötti magyar pszichológia történetéről ír, és azt a folyamatot vizsgálja, melynek so-

2 Vö. Máriási D. \& Vida K.: Kritikai pszichológiát! A pszichológia intézményrendszere a kritikai pszichológia perspektívájából. Imágó Budapest, 2015. Vol. 4. No. 2. rán a 70-es évekre a magyar pszichológia a korábbiakhoz képest sokkal inkább az egyénre és tüneteire koncentrált, alapértékévé tette a politikamentességet, és igyekezett elhatárolni magát még az oktatási rendszertől is. Lafferton Emese hasonló, de épp fordított irányú folyamatot elemez, amikor azt vizsgálja, hogy a 19. századi magyar pszichiátria miként terjesztette ki a hatókörét pszichiátriai szempontból releváns társadalmi problémákra.

A könyv számos tanulmánya foglalkozik különféle politikai rendszerek és események pszichotudományos intézményekre, pályákra, gyakorlatokra tett hatásával. A 2020-ban elhunyt Erős Ferenc egyik utolsó (még életében megjelent) tanulmánya szerepel a kötetben. A tanulmány Ferenczi Sándor munkásságát tárgyalja: hogyan alakultak, változtak Ferenczi - elsősorban is erőszakellenes, saját szavaival élve "liberális szocialista” - nézetei a történelem sodrásában? Kik és mik befolyásolták ezeket a változásokat? Borgos Anna tanulmánya pedig Bálint Alice munkásságának állít emléket: arra keresi a választ, hogy milyen szerepeket kapott Bálint Alice szakmai életében és politikai nézeteiben a pszichoanalízis.

$\mathrm{Az}$ intézményes, tágabb szakmai közeget érintő példák közt Máriási Dóra tanulmánya világít rá arra, hogy a magyar pszichológia Kádár-rendszer alatti újraintézményesülésének emlékezetében hogyan lepleződnek el intézménypolitikai kérdések - amelyekre természetesen erős hatással voltak a Kádár-rendszer nyújtotta lehetőségek és keretek. Ezek a kérdések azonban gyakran más, kevésbé politicizált keretben bukkannak fel, például az arról szóló vita képében, hogy melyek voltak a valóban „szakmai” ágak a pszichológia tudományában ebben az időszakban. Azt, hogy hasonló politikai hatások nem csak a múltban léteztek, jól mutatja Philip Tho- 
mas tanulmánya, aki a jelenleg is müködő neoliberális politikai tendenciák fényében fogalmazza meg az antipszichiátria kritikáját.

Itt érdemes megemlíteni Csabai Márta és Papp-Zipernovszky Orsolya tanulmányát is, amely azt világítja meg, hogy nemcsak a pszichológusoknak és pszichológiai intézményeknek, de a pszichológiai fogalmaknak, sőt, a mentális betegségeknek is van történetük. A szerzők kiindulási pontja, hogy a mentális betegségek meghatározásainak változása a diagnosztikai kézikönyvekben nem más, mint a tudománynak a környező társadalommal való bonyolult interakciója. Példájukban a trauma fogalmának változása a DSM diagnosztikus rendszerében egyrészt a társadalom alakulása által meghatározott, másrészt pedig különféle tudománypolitikai szereplők küzdenek a fogalom meghatározásáért és ezáltal a szociális világ alakításáért. Politika tehát az is, ahogyan a pszichotudományok egy-egy korszak emberképéhez, ideológiájához járulnak hozzá, pontosabban ahogyan interakcióba lépnek azzal. Erre erős példát hoz Agora Zsuzsanna és Rab Virág tanulmánya is: ők az első világháború német (hadügyi) pszichiátriájának domináns „traumapolitikáját" (261. o.) tárgyalják, amely a hazafiság és bátorság hiányának tekintette a háború okozta mentális sérüléseket.

Amint az a fentiekből is kiderül, a Psychology and Politics sok fejezete valójában a tudományos megismerés problémáival foglalkozik, és a hagyományos - (neo)pozitivista, a modernitás emberképéből következő - tudománykép kritikáját kínálja. A pszichotudományok művelöiként, amint arra Berkovits Balázs tanulmánya is ráirányítja a figyelmet, érdemes kritikusnak lennünk a "tudományos" és „morális” szempontok elkülönítésével a tudománytörténetben. Berkovits a pszichiátria olyan ismeretelméleti kritikáit elemzi, amelyek végső soron a következő érvre futnak ki: a pszichiátria egy-egy diagnózisa konstruált („kitalált”), és nem az "objektív” valóság leírására szolgál. Berkovits (Ian Hacking és Michel Foucault nyomán) amellett érvel, hogy attól, hogy valami konstruált, még lehet valóságos - sőt, épp ezáltal jön létre a társas valóság.

A pszichológiát és pszichiátriát - Foucault nyomán - több másik szerző is úgy értelmezi, mint a modernitás új szükségleteire felelő tudományágakat, amelyek fő célja, hogy létrehozzák az embernek és az ember megismerésének egy bizonyos (politikailag és ideológiailag meghatározott, sőt, hasznos) képét. Ebből a szempontból vizsgálja Gordana Jovanović is a pszichológia huszadik századi történetét. Állítása szerint a pszichológia (ahogy a modernitás emberképe is) az egyént helyezi a megismerés középpontjába, a társadalmi kontextust pedig másodlagosnak tekinti. Így gyakran a változtatás felelősségét is az egyén nyakába varrja, még olyankor is, amikor a probléma tömegeket érint, és társadalmi változással lenne megszüntethető. Ezzel összefüggésben a pszichológia - különösen a huszadik század háborúk sújtotta időszakaiban, mutatja be Jovanović - újra és újra a bizonyosság, az általános és változatlan tudás felé fordul, leegyszerüsítve ezzel az emberi tapasztalatok komplexitását. Bár számos kísérlet történt a pszichológia emberképének módosítására (ilyennek látja Jovanović a kognitív forradalom kezdetét és a kulturális pszichológiát), ezek a kísérletek sorra viszszatértek, visszatérnek az eredeti vágányra - emiatt (nemzet)politikai, sőt, alkalmanként akár háborús igények szolgálatába is állíthatók.

Még ha a pszichotudományok egy adott kor szubjektumainak kitermelésére (és így hatalomgyakorlásra) szolgálnak is, a kötet nem állítja azt, hogy ne lenne meg bennük 
a lehetőség az emberi szenvedés enyhítésére (201. o.). Milyen tudományos megközelítés és gyakorlat következik tehát a Psychology and Politics kritikáiból? A tanulmányokat természetesen leegyszerüsítő lenne közös, ellentmondások nélküli egységként kezelni, amely egy összefüggő stratégiát vázolna. Itt érdemes lehet azonban visszatérnünk a politikai elköteleződés kérdésére, és arra, hogy egészen pontosan mit is állít a könyv ezzel kapcsolatban.

Amint arra különböző nézőpontokból felhívják a figyelmet a kötetben (pl. Julia Borossa és Stephen Frosh szövegei), a társadalmi elnyomás és egyenlőtlenségek esetében az állásfoglalás semmiképpen sem megkerülhető a pszichotudományok művelöi számára. Ezekben az esetekben ugyanis bármi, ami nem aktív és tevőleges állásfoglalás az elesettek mellett, valójában fenntartja az elnyomás vagy egyenlőtlenség állapotát, így szenvedést okoz - ez pedig egy segítő szakma etikájával nem összeegyeztethető. Tehát annak felismerése, hogy a politika mindenütt jelen van az emberi társadalomban - így nem kiküsöbölhető a tudomány és a segítő szakmák működéséből sem -, egyben bizonyos fokú elkötelezettséget jelent az elesettek felé. ${ }^{3}$ A pszichoanalitikusi (és pszichológusi) neutralitás, amint azt Frosh megjegyzi, eredetileg arra vonatkozik, hogy a klienshez ítélkezés nélkül viszonyulunk, nem pedig arra a megalapozatlan elképzelésre, hogy a politika „külső” világa és a terápia élesen különválaszthatók - ez utóbbi elképzelés vezet végső soron a pszichoanalitikus (pszichológus) politikai konformizmusához (141, o.).

Ahhoz azonban, hogy a pszichotudományok müvelöi aktívan kiállhassanak a szenvedők mellett, elsősorban reflexióra van szükség. Ez részben a tudományos megismerés korlátaival és jellemzőivel való szembenézést, részben pedig a pszichotudományok saját történelmének ismeretét jelenti (annak sötét foltjaival együtt). A reflexiónak ebben a munkájában nyújt támpontot a Psychology and Politics.

A szerzők emiatt maguk sem törekszenek a politikamentességre: a legtöbb tanulmánynak van (implicit és tágan értelmezett) politikai, társadalmi elköteleződése. Ezek a legtöbbször demokratikus értékeket, a társadalmi egyenlőtlenségek elleni állásfoglalást, erőszakellenes álláspontot jelentenek. Néhány tanulmány szerzője pedig kimondottan valamilyen politikai irányzattal vagy eszmével azonosul (pl. Dennis Fox az anarchista mozgalmakkal).

A cikk a Creative Commons Attribution 4.0 International License (https://creativecommons.org/licenses/ by-nc/4.0/) feltételei szerint publikált Open Access közlemény, melynek szellemében a cikk bármilyen médiumban szabadon felhasználható, megosztható és újraközölhető, feltéve, hogy az eredeti szerző és a közlés helye, illetve a CC License linkje és az esetlegesen végrehajtott módosítások feltüntetésre kerülnek. 